\title{
KEEFEKTIFAN METODE KOMPREHENSIF UNTUK PENGEMBANGAN NILAI NASIONALISME DALAM PEMBELAJARAN PPKn DI SMPIT ABU BAKAR YOGYAKARTA
}

\author{
Nufikha Ulfah, Darmiyati Zuchdi \\ Program Studi Ilmu Pengetahuan Sosial (IPS), Konsentrasi PKn, Universitas Negeri Yogyakarta \\ nufikhau@ymail.com, darmiyatiz@yahoo.com
}

\begin{abstract}
Abstrak
Penelitian ini bertujuan untuk mengetahui: (1) perbedaan pada pemahaman nilai nasionalisme siswa yang mengikuti pembelajaran PPKn dengan metode komprehensif dan siswa yang mengikuti pembelajaran dengan metode konvensional; (2) perbedaan pada sikap terhadap nilai nasionalisme siswa yang mengikuti pembelajaran PPKn dengan metode komprehensif dan siswa yang mengikuti pembelajaran dengan metode konvensional; dan (3) keefektifan metode komprehensif untuk pengembangan nilai nasionalisme (pemahaman dan sikap terhadap nilai nasionalisme) dibandingkan dengan metode konvensional. Penelitian ini merupakanpenelitian quasi eksperimen dengan desain pretest-posttest control group design. Populasi penelitian siswa kelas VIII, sampel dipilih dengan teknik random sampling (kelas eksperimen dan kelas kontrol). Teknik pengumpulan data menggunakan tes, nontes, dan observasi. Teknik analisis data menggunakan MANOVA. Hasil penelitian menunjukkan bahwa: (1) terdapat perbedaan pemahaman nilai nasionalisme siswa kelas eksperimen (metode komprehensif) dan kelas kontrol (metode konvensional); (2) terdapat perbedaan sikap terhadap nilai nasionalisme siswa kelas eksperimen (metode komprehensif) dan siswa kelas kontrol (metode konvensional); dan (3) metode komprehensif lebih efektif untuk pengembangan nilai nasionalisme (pemahaman dan sikap terhadap nilai nasionalisme).
\end{abstract}

Kata kunci:metode komprehensif, pemahaman nilai nasionalisme, sikap terhadap nilai nasionalisme

\section{THE EFFECTIVENESS OF THE COMPREHENSIVE METHOD FOR THE DEVELOPMENT OF THE VALUE OF NATIONALISM IN LEARNING CIVIC EDUCATION AT SMPIT ABU BAKAR YOGYAKARTA}

\author{
Nufikha Ulfah, Darmiyati Zuchdi \\ Program Studi Ilmu Pengetahuan Sosial (IPS), Konsentrasi PKn, Universitas Negeri Yogyakarta \\ nufikhau@ymail.com, darmiyatiz@yahoo.com
}

\begin{abstract}
This study aims to determine: 1) the difference between the understanding of the value of nationalism of the students who take the Civic Education course with the comprehensive method and those with the conventional method; 2) the difference of attitudes toward the value of nationalism between the students who take the Civic Education course with the comprehensive method and those with the conventional method and; 3) the effectiveness of the comprehensive method for the development of the value of nationalism (comprehension of the value of nationalism and attitudes towards the value of nationalism) compared to the conventional method in learning Civic Education. This research was a quasi-experimental design with pre-test and post-test control group design. The population in this study was all the students of the eighth grade, the sample was selected by the random sampling technique (experimental class and control class). The data collection techniques used a test, non-test and observations. The data were analyzed using MANOVA. The results shows that: (1) there is a difference between the understanding of the value of nationalism of the students who take the Civic Education course with the comprehensive method and those with the conventional method; (2) there is a difference of attitudes towards the value of nationalism between the students who take the Civic Education course with the comprehensive method and those with the conventional method; and (3) the comprehensive method is more effective for the development of the value of nationalism (comprehension of the value of nationalism and attitudes towards the the value of nationalism).

Keywords: comprehensive method, nationalism value understanding, attitudes towards the nationalism values
\end{abstract}




\section{Pendahuluan}

Seiring dengan bergulirnya arus globalisasi, memberikan dampak dalam berbagai aspek kehidupan berbangsa dan bernegara. Baik dampak positif maupun negatif. Lunturnya nilai dan sikap generasi muda akan nasionalisme seperti dalam kegiatan upacara bendera, siswa sekolah menengah kurang khidmat, maraknya tawuran antarpelajar, gaya hidup yang konsumerisme, lunturnya semangat gotong royong, kurangnya penghargaan terhadap budaya lokal dan meninggalkan hasil produk dalam negeri. Keadaan yang dianggap rancu saat ini, sedikit banyak dipengaruhi oleh pemahaman yang parsial terhadap nilai-nilai luhur bangsa. Hal ini juga membawa dampak terhadap sikap siswa/generasi muda terhadap nilai-nilai nasionalisme. Terkait rendahnya pemahaman generasi muda akan nasionalisme serta nilai-nilai yang terkandung di dalamnya. Pemahaman mengenai nilai Pancasila pada siswa SMP, dominan pada kategori kurang paham dengan persentase $42 \%$ (Puspita, Hasyim \& Yanzi, 2013, p. 2).

Semangat kebangsaan atau nasionalisme harus dipelihara dan dikembangkan agar relevan dengan tantangan masa kini. Berkaitan dengan konsep nasionalisme, Anderson mendefinisikan nation sebagai suatu komunitas politik yang dibayangkan dan sekaligus sebagai suatu yang inheren terbatas dan berdaulat. Irwan Abdullah (2000) mengungkapkan bahwa kondisi objektif yang saat ini dihadapi bangsa Indonesia merupakan kondisi parah dalam berbagai dimensi, mulai dari terbatasnya masalah jaminan publik, kualitas manusia yang rendah, konflik dan kekerasan yang mengemuka, hingga pada persoalan rendahnya kredibilitas pemerintah. Selanjutnya, Maarif 2001) mengungkapkan bahwa kondisi Indonesia saat ini diibaratkan kapal bocor yang sedang oleng, terapung di laut lepas menunggu karam, dan nahkodanya seperti kehilangan arah (Sadono, 2014, p.72).

Berdasarkan hasil observasi dan wawancara yang dilakukan di SMPIT Abu Bakar Yogyakarta pada tanggal 3-13 Februari 2015, diperoleh informasi bahwa sekitar tahun 2009 SMPIT Abu Bakar mendapatkan teguran dari Dinas Pendidikan yang tengah melakukan supervisi agar melaksanakan kegiatan upacara bendera setiap hari senin, karena sejak berdirinya sekolah tersebut (2002-2009) tidak pernah melakukan kegiatan upacara bendera seperti yang dilakukan oleh sekolah-sekolah lainnya setiap hari senin. Pada saat dilakukan observasi pada kegiatan upacara bendera, masih banyak sikap siswi yang kurang khidmat (pelaksanaan upacara antara siswa dan siswi bergantian dan terpisah), dapat dilihat pada saat pengibaran bendera sikap mereka kurang sempurna dan terlihat main-main. Teks Pancasila dan Pembukaan UUD 1945 tidak dibacakan pada saat Apel Senin (Apel Senin, istilah yang digunakan untuk mengganti istilah Upacara Pengibaran Bendera di SMPIT Abu Bakar Yogyakarta). Guru belum maksimal dalam mengembangkan pemahaman nilai nasionalisme kepada peserta didik.

Menanggapi permasalahan tersebut, perlu adanya modal besar yang dilandasi dengan komitmen nilai kebangsaan serta moral religius sebagai usaha membangun/menata kembali ikatan kebangsaan (nasionalisme) yang mengikat negara, masyarakat, dan kebudayaan dalam wilayah Negara Kesatuan republik Indonesia. Aktualisasi nilai-nilai nasionalisme dapat ditunjukkan melalui upaya penanaman: (a) rasa bangga sebagai Bangsa Indonesia; b) rasa cinta tanah air; c) rela berkorban demi bangsa; d) menerima kemajemukan; e) rasa bangga pada budaya yang beraneka ragam; f) menghargai jasa para pahlawan; dan g) mengutamakan kepentingan umum (Aman, 2014).

Selain itu, upaya yang dapat dilakukan untuk menggalakkan kembali semangat nasionalisme melalui pengintegrasian nilainilai nasionalisme dengan kegiatan pembiasaan yang dimulai dari jenjang pendidikan dasar. Berdasarkan hasil penelitian yang dilakukan oleh Muthoharoh, Tijan \& Suprayogi (2012) penerapan kegiatan pembiasaan pada siswa SD Negeri Kuningan 02 Semarang Utara mendapat respon yang beragam, terdapat siswa yang antusias dan penuh semangat. Dapat dilihat dari sikap siswa antusias berangkat sekolah tepat waktu dan mempersiapkan segala sesuatunya dengan baik, begitu bel berbunyi mereka segera bergegas menuju lapangan upacara, dalam pelaksanaan upacara penuh khidmat. Namun terdapat pula siswa yang kurang semangat, mereka terlihat jenuh dalam melaksanakan kegiatan pembiasaan.

$\mathrm{PKn} / \mathrm{PPKn}$ merupakan salah satu mata pelajaran yang sangat berguna dalam upaya pengembangan nilai nasionalisme siswa. 
Adapun visi dan misinya yaitu membentuk warga negara yang baik yang memiliki watak kebangsaan (nation and character building). Sebaiknya PKn/PPKn tidak hanya berorientasi kognitif saja, tetapi akan lebih baik jika $\mathrm{PKn} / \mathrm{PPKn}$ menjadi program pendidikan nilai yang komprehensif. CCE (1994) menjelaskan paradigma baru pembelajaran PPKn secara holistik memiliki tujuan membentuk warga negara muda (young citizen) memiliki rasa kebangsaan dan cinta tanah air, dalam konteks nilai dan moral Pancasila, nilai dan norma UUD 1945, nilai dan komitmen Bhinneka Tunggal Ika serta komitmen dalam NKRI. Secara psikopedagogis dan sosiokultural, sebagai upaya pengembangan kecerdasan kewarganegaraan (civic intellegence) secara psikososial tercermin pada penguasaan pengetahuan kewarganegaraan (civic knowledge), perwujudan sikap kewarganegaraan (civic dispositions), dan penampilan keterampilan kewarganegaraan (civic skills) yang kesemuanya mengkristal kembali menjadi kebijakan kewarganegaraan (civic virtues/civility) (Winataputra, 2014, pp. 4-5).

Berdasarkan uraian tersebut, perlu adanya program pendidikan nilai yang komprehensif dalam pembelajaran PPKn. Untuk itu, peneliti tertarik mengadakan penelitian di SMPIT Abu Bakar Yogyakarta terkait keefektifan penerapan metode komprehensif sebagai metode dari pendekatan yang comprehensive seperti yang diutarakan oleh Kirschenbaum (1995, pp. 31-42) yang meliputi: inculcation, modelling, facilitation, dan skill building, untuk pengembangan nilai nasionalisme (pemahaman nilai nasionalisme dan sikap terhadap nilai nasionalisme) dan untuk melihat perbedaan dari pemahaman nilai nasionalisme dan sikap terhadap nilai nasionalisme antara siswa yang menggunakan metode komprehensif dan yang tidak menggunakan.

\section{Metode Penelitian}

\section{Jenis Penelitian}

Penelitian ini merupakan penelitian eksperimen dengan metode quasi eksperimen (eksperimen semu) dengan desain pretestposttest control group design. Metode quasi eksperimen dalam penelitian ini digunakan karena peneliti ingin mengetahui perbedaan pemahaman nilai nasionalisme dan sikap terhadap nilai nasionalisme antara siswa yang diberikan perlakuan dengan metode konvensional (kelas eksperimen) dan siswa yang tidak diberikan perlakuan dengan metode komprehensif (kelas kontrol), terdapat dua kelompok yang dibandingkan.

\section{Waktu dan Tempat Penelitian}

Penelitian dilaksanakan pada siswa kelas VIII di SMPIT Abu bakar Yogyakarta. Adapun waktu penelitiannya dilaksanakan mulai bulan Februari-Mei 2015 pada semester genap T.P 2014/2015.

\section{Target/Subjek Penelitian}

Populasi dalam penelitian ini adalah seluruh siswa kelas VIII SMPIT Abu Bakar Yogyakarta. Pengambilan sampel dilakukan dengan random sampling pada kelas-kelas Boarding School dengan pertimbangan bahwa kelas boarding school (VIIIA, VIIIB, VIIIE, dan VIIIF) mendapatkan fasilitas dan pembelajaran yang lebih jika dibandingkan dengan kelas-kelas fullday school (VIIIC, VIIID, VIIIG, dan VIIIH)

\section{Prosedur}

Prosedur penelitian ini yaitu1) mengajukan perizinan ke sekolah untuk melakukan pra suvey dan dilanjutkan dengan penelitan; 2) menentukan kelompok eksperimen dan kelompok kontrol; 3) sebelum perlakuan, kedua kelompok dilakukan pretest berupa soal tes dan angket; 4) memberikan perlakuan kepada kelompok eksperimen; 5) setelah diberikan perlakuan/tritmen, kedua kelompok dilakukan posttest dengan menggunakan soal tes dan angket yang sama pada saat pretest.

\section{Data, Intrumen, dan Teknik Pengumpulan Data}

Teknik pengumpulan data dalam penelitian ini meliputi tes, nontes, dan observasi. Tes diberikan untuk mengukur perbedaan peningkatan pemahaman nilai nasionalisme siswa yang berbentuk pilihan pilihan ganda (multiple choice), tes dilakukan sebanyak dua kali yaitu pretest dan posttest pada kedua kelompok (eksperimen dan kontrol). Nontes dengan angket diberikan dengan tujuan untuk mengetahui perbedaan peningkatan sikap terhadap nilai nasionalisme pada kedua kelom- 
pok (eksperimen dan kontrol) melalui pretest dan posttest. Sedangkan observasi dilakukan untuk mengetahui penerapan metode komprehensif pada pembelajaran PPKn.

Teknik Analisis Data

\section{Statistik Deskriptif}

Statistik Deskriptif digunakan untuk menyajikan data yang diperoleh melalui tes untuk mengukur perbedaan pemahaman nilai nasionalisme kedua kelompok (eksperimen dan kontrol) nontes berupa angket Skala Likert untuk mengukur perbedaan sikap terhadap nilai nasionalisme pada kedua kelompok (eksperimen dan kontrol) dalam bentuk tabel (distribusi frekuensi, ukuran pemusatan, ukuran letak, maupun ukuran keragaman) gambar, diagram maupun grafik.

\section{Statistik Inferensial}

Uji Prasyarat Analisis. Uji normalitas digunakan untuk mengatahui apakah data berdistribusi normal atau tidak yang dilakukan dengan Kolmogrov-Smirnov dengan bantuan SPSS 16.0, data dapat dikatakan normal apabila sig. $>0,05$.

Uji homogenitas dilakukan untuk mencari tahu apakah kelompok memiliki variansi yang sama tau tidak. Uji homogenitas terhadap tes pemahaman nilai nasionalisme dan sikap terhadap nilai nasionalisme secara sendiri-sendiri menggunakan Lavene Test, dan Uji Box's M digunakan untuk menguji homogenitas terhadap pemahaman nilai nasionalisme dan sikap terhadap nilai nasionalisme secara bersama-sama.

\section{Uji Hipotesis}

Pengujian hipotesis dalam penelitian ini digunakan statistik inferensial yaitu MANOVA (Multivariate Analysis of Variance). Adapun rumusan hipotesis dalam penelitian ini (1) $\mathrm{H}_{\mathrm{a}}$ : terdapat perbedaan pengembangan pada pemahaman nilai nasionalisme antara kelas eksperimen (menngunakan metode komprehensif) dengan siswa kelas kontrol (menggunakan metode konvensional) dalam pembelajaran PPKn; (2) $\mathrm{H}_{\mathrm{a}}$ : terdapat perbedaan pengembangan pada sikap terhadap nilai nasionalisme siswa kelas eksperimen (menggunakan metode komprehensif) dengan siswa kelas kontrol (menggunakan metode konvensional)dalam pembelajran PPKn; dan (3)
$\mathrm{H}_{\mathrm{a}}$ : metode komprehendif efektif untuk mengembangkan nilai nasionalisme siswa (pemahaman nilai nasionalisme dan sikap terhadap nilai nasionalisme dalam pebelajaran PPKn. $\mathrm{H}_{\mathrm{a}}$ dapat diterima jika $\rho<0,05$, sebaliknya jika $\rho>0,05$ maka $H_{a}$ ditolak.

\section{Hasil Penelitian dan Pembahasan}

\section{Deskripsi Data Pemahaman Nilai Nasionalisme}

Data hasil tes pemahaman nilai nasionalisme yang terdiri atas data pretest dan posttest pada kedua kelompok disajikan pada Tabel 1.

Tabel 1. Rangkuman Deskripsi Data Tes Pemahaman Nilai Nasionalisme

\begin{tabular}{ccccc}
\hline Deskripsi & \multicolumn{2}{c}{$\begin{array}{c}\text { Kelompok } \\
\text { Eksperimen } \\
(\mathrm{n}=23)\end{array}$} & \multicolumn{2}{c}{$\begin{array}{c}\text { Kelompok } \\
\text { Kontrol } \\
(\mathrm{n}=34)\end{array}$} \\
\cline { 2 - 5 } & $\begin{array}{c}\text { Pre- } \\
\text { test }\end{array}$ & $\begin{array}{c}\text { Post- } \\
\text { test }\end{array}$ & $\begin{array}{c}\text { Pre- } \\
\text { test }\end{array}$ & $\begin{array}{c}\text { Post- } \\
\text { test }\end{array}$ \\
\hline Rata-rata & 7,13 & 8,57 & 7,36 & 7,96 \\
Std. Deviasi & 0,70 & 0,90 & 0,74 & 0,73 \\
\hline
\end{tabular}

Berdasarkan kriteria ketuntasan minimal, hasil pretest kelas eksperimen yang belum mencapai KKM dengan kategori kurang sebanyak 4 siswa dan sebanyak 17 siswa masuk dalam kategori cukup, sedangkan siswa yang telah memenuhi KKM sebanyak 2 siswa. Pada kelas kontrol terdapat 3 siswa yang masuk dalam kategori kurang, 23 siswa masuk dalam kategori cukup, 7 siswa masuk dalam kategori baik, dan sebanyak 1 siswa masuk dalam kategori sangat baik. Untuk selengkapnya dapat dilihat pada Tabel 2 dan Gambar 1.

Tabel 2. Perbandingan Frekuensi Hasil Pretest Pemahaman Nilai Nasionalisme

\begin{tabular}{|c|c|c|c|c|c|}
\hline \multirow[t]{2}{*}{ Kategori } & \multirow[t]{2}{*}{$\begin{array}{c}\text { Rentang } \\
\text { Skor }\end{array}$} & \multicolumn{2}{|c|}{$\begin{array}{c}\text { Kelas } \\
\text { Eksperimen }\end{array}$} & \multicolumn{2}{|c|}{$\begin{array}{l}\text { Kelas } \\
\text { Kontrol }\end{array}$} \\
\hline & & $\mathrm{f}$ & $\%$ & $\mathrm{f}$ & $\%$ \\
\hline Kurang & $<6,7$ & 4 & 17,4 & 3 & 8,8 \\
\hline Cukup & $6,7-7,7$ & 17 & 73,9 & 23 & 67,6 \\
\hline Baik & $7,8-8,8$ & 2 & 8,7 & 7 & 20,6 \\
\hline Sangat Baik & $8,9-10$ & 0 & 0,0 & 1 & 2,9 \\
\hline \multicolumn{2}{|c|}{ Total } & 23 & 100 & 34 & 100 \\
\hline
\end{tabular}




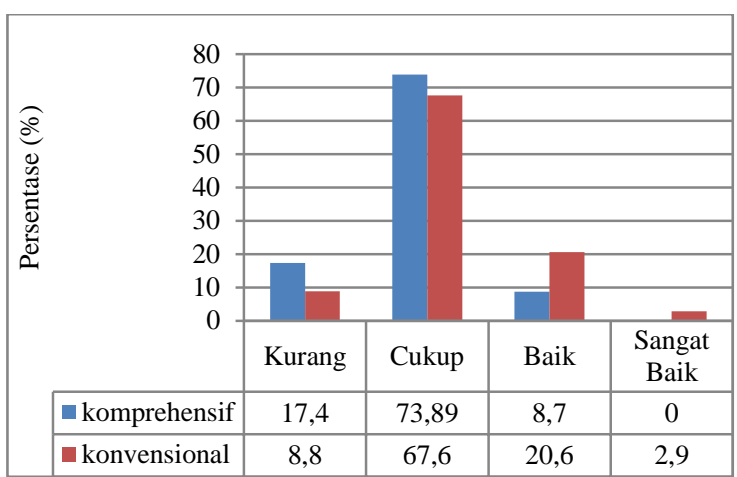

Gambar 1. Perbandingan Frekuensi Hasi Pretet Pemahaman Nilai Nasionalisme

Perbandingan hasil pretest pemahaman nilai nasionalisme pada kedua kelas (eksperimen dan kontrol) dengan indikator: (a) kebanggaan sebagai Bangsa Indonesia; (b) Cinta tanah air dan bangsa; (c) rela berkorban demi bangsa; (d) menerima kemajemukan; (e) menghargai budaya yang beraneka ragam; (f) menghargai jasa para pahlawan; (g) mengutamakan kepentingan umum dan rasa persatuan; dan (h) patriotisme dan berprestasi, dapat dilihat pada grafik berikut.

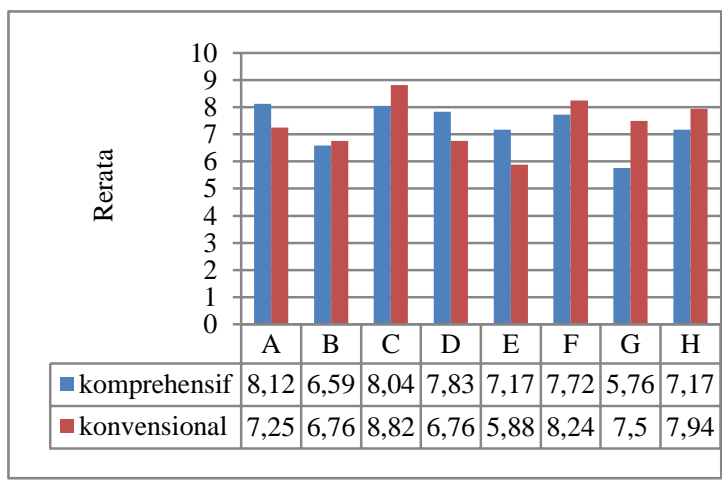

Gambar 2. Perbandingan Rerata Hasil Pretest setiap Indikator Pemahaman Nilai Nasionalisme

Setelah mengetahui kemampuan awal kedua kelompok, langkah selanjutnya yaitu memberikan perlakuan yaitu dengan menggunakan metode komprehensif untuk kelas eksperimen dan metode konvensional pada kelas kontrol. Kemudian kedua kelompok dilakukan posttest. Hasil posttest kedua kelompok diketahui pada kelas eksperimen sebanyak 4 siswa masuk dalam kategori cukup, 10 siswa masuk dalam kategori baik dan sebanyak 9 siswa yang masuk dalam kategori sangat baik. Sedangkan pada hasil posttest kelas kontrol sebanyak 2 siswa masuk dalam kategori kurang, 8 siswa pada kategori cukup, 23 siswa dengan kategori baik, dan 1 siswa dengan kategori sangat baik. Selengkapnya dapat dilihat pada tabel dan grafik berikut.

Tabel 3. Perbandingan Frekuensi Hasil Posttest Pemahaman Nilai Nasionalisme

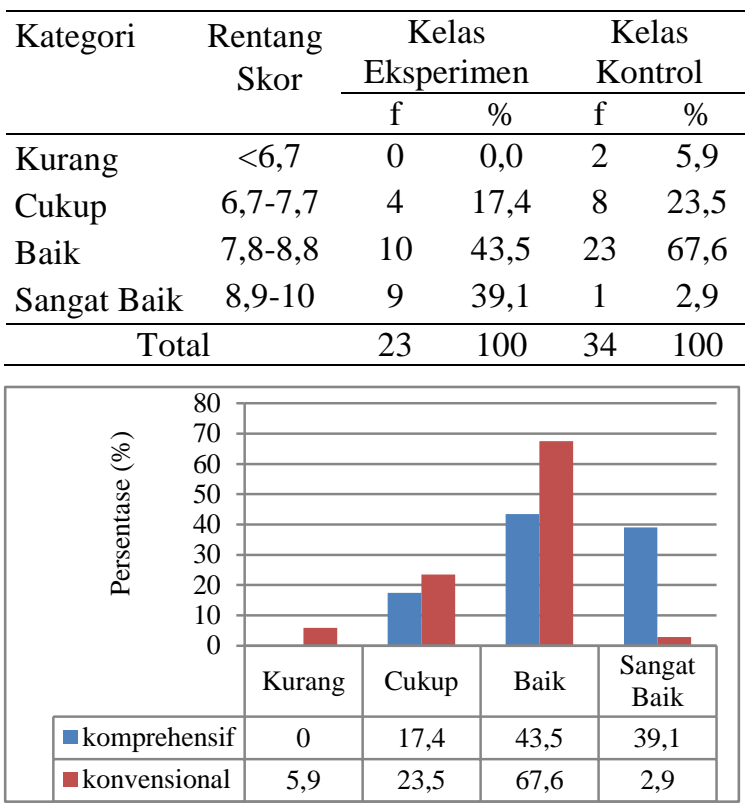

Gambar 3. Perbandingan Frekuensi Posttest Pemahaman Nilai Nasionalisme

Selanjutnya, data perbandingan hasil posttest berdasarkan indikator pemahaman nilai nasionalisme akan disajikan pada grafik Gambar 4.

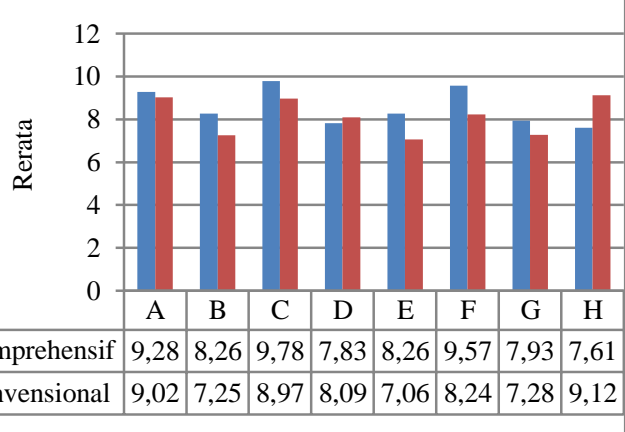

Gambar 4. Perbandingan Rerata Hasil Posttest Indikator Pemahaman Nilai Nasionalisme

Grafik perbandingan rerata hasil posttest indikator pemahaman nilai nasionalis-me menunjukkan bahwa terdapat perbedaan peningkatan terhadap skor rerata pemahaman nilai nasionalisme setelah diberikan perlakuan 
dengan indikator A, B, C, E, F, dan G kelas eksperimen lebih tinggi dibandingkan dengan kelas kontrol. Namun pada indikator D dan $\mathrm{H}$ kelas eksperimen lebih rendah dibandingkan kelas kontrol.

Deskripsi Data Sikap terhadap Nilai Nasionalisme

Deskripsi statistik mengenai data sikap terhadap nilai nasionalisme kedua kelompok yang diperoleh melalui pretest dan posttest secara ringkas ditunjukkan pada Tabel 4.

Tabel 4. Rangkuman Deskripsi Data Sikap terhadap Nilai Nasionalisme

\begin{tabular}{lcccc}
\hline Deskripsi & $\begin{array}{c}\text { Kelompok } \\
\text { Eksperimen } \\
(\mathrm{n}=23)\end{array}$ & \multicolumn{2}{c}{$\begin{array}{c}\text { Kelompok } \\
\text { Kontrol } \\
(\mathrm{n}=34)\end{array}$} \\
\cline { 2 - 5 } & $\begin{array}{c}\text { Pre- } \\
\text { test }\end{array}$ & $\begin{array}{c}\text { Post- } \\
\text { test }\end{array}$ & $\begin{array}{c}\text { Pre- } \\
\text { test }\end{array}$ & $\begin{array}{c}\text { Post- } \\
\text { test }\end{array}$ \\
\hline Rata-rata & 3,74 & 4,36 & 3,74 & 4,00 \\
Std. Deviasi & 0,28 & 0,19 & 0,28 & 0,30 \\
\hline
\end{tabular}

Data sikap terhadap nilai nasionalisme siswa selanjutnya dikonversikan kedalam penentuan kriteria. Penentuan kriteria mengacu pada rumus yang dikembangkan oleh Mardapi (2008, p.12), selengkapnya dapat dilihat pada tabel dan grafik berikut.

Tabel 5. Perbandingan Frekuensi Pretest Sikap terhadap Nilai Nasionalisme

\begin{tabular}{lccccc}
\hline \multirow{2}{*}{ Kategori } & \multirow{2}{*}{$\begin{array}{c}\text { Rentang } \\
\text { Skor }\end{array}$} & \multicolumn{2}{c}{$\begin{array}{c}\text { Kelas } \\
\text { Eksperimen }\end{array}$} & \multicolumn{2}{c}{$\begin{array}{c}\text { Kelas } \\
\text { Kontrol }\end{array}$} \\
\cline { 3 - 6 } & & $\mathrm{f}$ & $\%$ & $\mathrm{f}$ & $\%$ \\
\hline Kurang & $1,00-1,99$ & 0 & 0,0 & 0 & 0,0 \\
Cukup & $2,00-2,99$ & 0 & 0,0 & 0 & 0,0 \\
Baik & $3,00-3,99$ & 18 & 78,3 & 28 & 82,4 \\
Sangat Baik & $4,00-5,00$ & 5 & 21,7 & 6 & 17,6 \\
\hline Total & & 23 & 100 & 34 & 100 \\
\hline
\end{tabular}

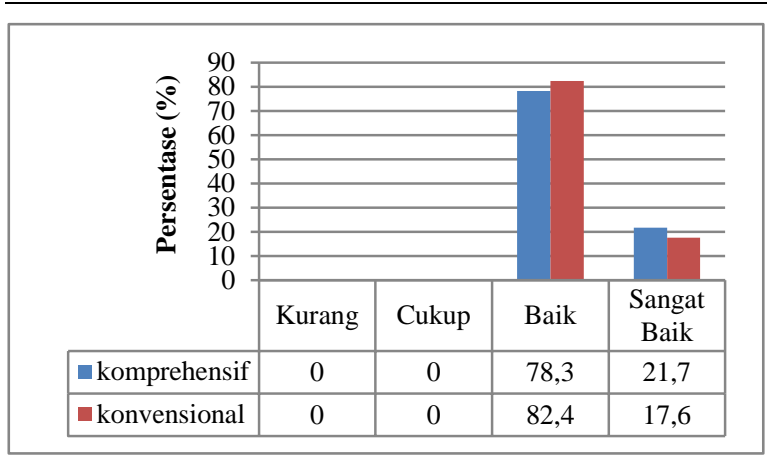

Gambar 5. Grafik Perbandingan Frekuensi

Hasil Pretest Sikap terhadap Nilai Nasionalisme
Data perbandingan hasil pretest sikap terhadap nilai nasionalisme dengan indikator (a) Kebanggaan sebagai Bangsa Indonesia; (b) Cinta tanah air dan bangsa; (c) Rela berkorban demi bangsa; (d) Menerima kemajemukan; (e) Menghargai budaya yang beraneka ragam; (f) menghargai jasa para pahlawan; (g) mengutamakan kepentingan umum dan rasa persatuan; dan (h) Patriotisme dan berprestasi, pada kedua kelompok yang disajikan pada Gamabr 6 .

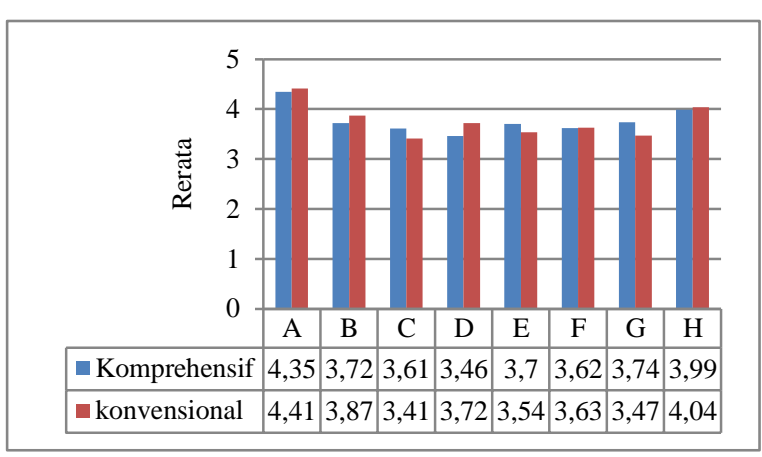

Gambar 6. Grafik Perbandingan Rerata Hasil Pretest Indikator Sikap terhadap Nilai Nasionalisme

Setelah mengetahui kemampuan awal kedua kelompok, langkah selanjutnya yaitu memberikan perlakuan terhadap kelompok eksperimen dengan menggunakan metode komprehensif pada pembelajaran PPKn dan metode konvensional digunakan pada kelas kontrol kemudian diakhiri dengan posttest. Selengkapnya untuk mengetahui perbandingan frekuensi berdasarkan hasil posttest sikap terhadap nilai nasionalisme kelas eksperimen dan kelas kontrol setelah perlakuan, dapat dilihat pada Tabel 6 dan Gambar 7.

Selanjutnya, data perbandingan hasil posttest sikap terhadap nilai nasionalisme yang akan dideskripsikan mengenai indikator sikap terhadap nilai nasionalisme, dapat dilihat pada grafik yang disajikan pada Gambar 8.

Tabel 6. Perbandingan Frekuensi Posttest Sikap terhadap Nilai Nasionalisme

\begin{tabular}{lccccc}
\hline Kategori & $\begin{array}{c}\text { Rentang } \\
\text { Skor }\end{array}$ & \multicolumn{2}{c}{$\begin{array}{c}\text { Kelas } \\
\text { Eksperimen }\end{array}$} & \multicolumn{2}{c}{$\begin{array}{c}\text { Kelas } \\
\text { Kontrol }\end{array}$} \\
\cline { 3 - 6 } & & $\mathrm{f}$ & $\%$ & $\mathrm{f}$ & $\%$ \\
\hline Kurang & $1,00-1,99$ & 0 & 0,0 & 0 & 0,0 \\
Cukup & $2,00-2,99$ & 0 & 0,0 & 0 & 0,0 \\
Baik & $3,00-3,99$ & 1 & 4,3 & 16 & 47,1 \\
Sangat Baik & $4,00-5,00$ & 22 & 95,7 & 18 & 52,9 \\
\hline \multicolumn{2}{c}{ Total } & 23 & 100 & 34 & 100 \\
\hline
\end{tabular}




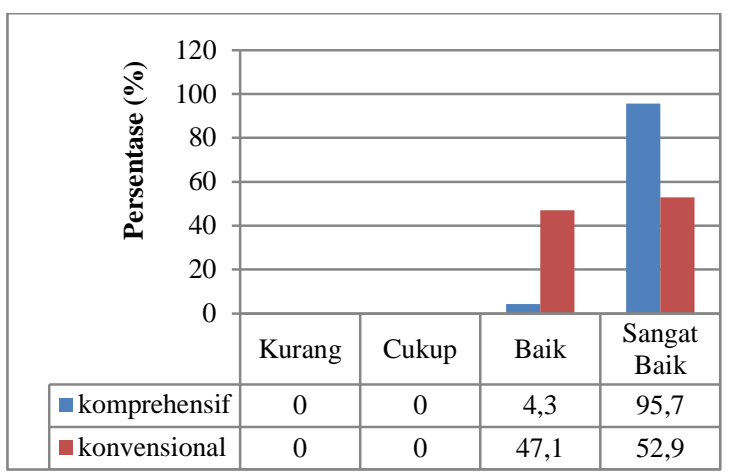

Gambar 7. Grafik Perbandingan Frekuensi Posttest Sikap terhadap Nilai Nasionalisme

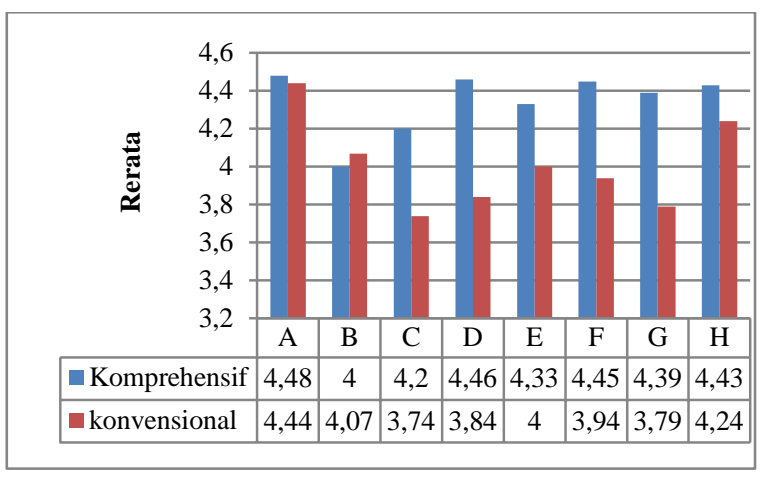

Gambar 8. Grafik Perbandingan Rerata Hasil Posttest Indikator Sikap terhadap Nilai Nasionalisme

Grafik perbandingan rerata hasil posttest indikator sikap terhadap nilai nasionalisme menunjukkan bahwa terdapat perbedaan terhadap skor rereta pada kedua kelas (eksperimen dan kontrol) setelah diberikan perlakuan, skor rerata dari masing-masing indikator kelas eksperimen lebih tinggi dibandingkan kelas kontrol, dapat diartikan bahwa metode komprehensif efektif dalam mengembangkan sikap terhadap nilai nasionalisme.

Peningkatan Skor Pemahaman Nilai Nasionalisme dan Sikap terhadap Nilai Nasionalisme

\section{Peningkatan Pemahaman Nilai Nasionalisme}

Peningkatan pemahaman nilai nasionalisme diperoleh melalui selisih antara dua tes yaitu selisih skor rerata pretest dan skor rerata posttest pada kedua kelompok dengan tujuan untuk mengetahui apakah peningkatan pemahaman nilai nasionalisme siswa kelas eksperimen lebih tinggi dibandingkan dengan siswa pada kelas kontrol. Berdasarkan data yang telah diperoleh, peningkatan yang terjadi pada kelas eksperimen sebesar 73,9\% dengan frekuensi 17 dan pada kelas kontrol sebesar $69,6 \%$ dengan frekuensi 16 , dalam hal ini peningkatan yang terjadi pada kelas eksperimen lebih besar dari kelas kontrol, dapat dilihat pada Tabel 7.

Tabel 7. Persentase Perbandingan

Peningkatan Frekuensi Pemahaman Nilai Nasionalisme

\begin{tabular}{|c|c|c|c|c|c|c|c|}
\hline \multirow{2}{*}{ Metode } & \multirow{2}{*}{$\begin{array}{c}\text { Batasan } \\
\text { Skor }\end{array}$} & \multicolumn{2}{|c|}{ Pretest } & \multicolumn{2}{|c|}{ Posttest } & \multicolumn{2}{|c|}{$\begin{array}{c}\text { Pening- } \\
\text { katan }\end{array}$} \\
\hline & & $\mathrm{f}$ & $\%$ & $\mathrm{f}$ & $\%$ & $\mathrm{f}$ & $\%$ \\
\hline \multirow[t]{2}{*}{ M. Komp. } & $<7,8$ & 21 & 91,3 & 4 & 17,4 & & \\
\hline & $\geq 7,8$ & 2 & 8,7 & 19 & 82,6 & 17 & 73,9 \\
\hline \multicolumn{2}{|c|}{ Total } & 23 & 100 & 23 & 100 & & \\
\hline \multirow[t]{2}{*}{ M. Kon. } & $<7,8$ & 26 & 76,5 & 10 & 29,4 & & \\
\hline & $\geq 7,8$ & 8 & 23,5 & 24 & 70,6 & 16 & 69,6 \\
\hline \multicolumn{2}{|c|}{ Total } & 34 & 100 & 34 & 100 & & \\
\hline
\end{tabular}

Keterangan:

M. Komp: Metode Komprehensif

M. Kon : Metode Konvensional

Selanjutnya perbandingan peningkatan rerata setiap indikator pemahaman nilai nasionalisme, dapat dilihat pada grafik yang disajikan pada Gambar 9.

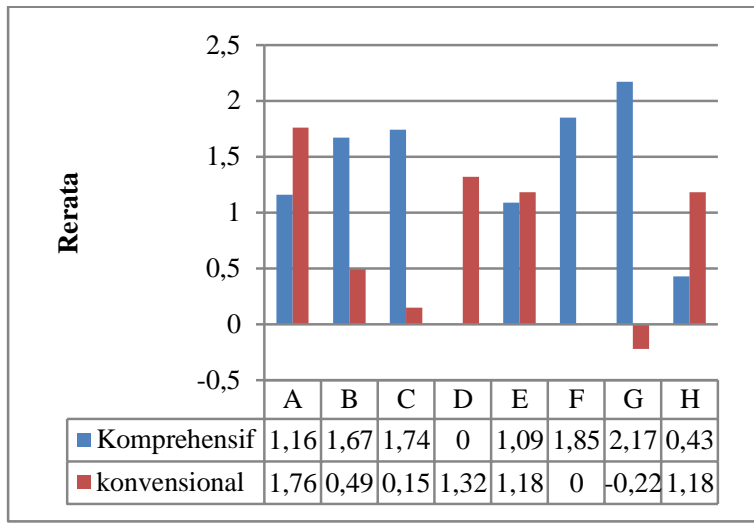

Gambar 9. Grafik Perbandingan Rerata Indikator Pemahaman Nilai Nasionalisme

Peningkatan Sikap terhadap Nilai Nasionalisme

Peningkatan sikap terhadap nilai nasionalisme diperoleh melalui selisih antara perolehan dua skor data angket, yaitu selisih skor hasil angket akhir dan skor hasil angket awal pada kelas eksperimen dan kelas kontrol. Adapun peningkatan yang terjadi pada kelas eksperimen sebesar $73,9 \%$ dengan frekuensi 
17 dan pada kelas eksperimen sebesar 52,2\% dengan frekuensi 12, disajikan pada Tabel 8.

Tabel 8. Perbandingan Persentase Peningkatan Frekuensi Sikap terhadap Nilai nasionalisme

\begin{tabular}{cccccccc}
\hline \multirow{2}{*}{ Metode } & $\begin{array}{c}\text { Batasan } \\
\text { Skor }\end{array}$ & \multicolumn{2}{c}{ Pretest } & \multicolumn{2}{c}{ Posttest } & \multicolumn{2}{c}{$\begin{array}{c}\text { Pening- } \\
\text { katan }\end{array}$} \\
\cline { 3 - 8 } & & $\mathrm{f}$ & $\%$ & $\mathrm{f}$ & $\%$ & $\mathrm{f}$ & $\%$ \\
\hline M. & $<4,00$ & 18 & 78,3 & 1 & 4,3 & & \\
Komp. & $\geq 4,00$ & 5 & 21,7 & 22 & 95,7 & 17 & 73,9 \\
\hline \multicolumn{2}{c}{ Total } & 23 & 100 & 23 & 100 & & \\
\hline M. Kon. & $<4,00$ & 28 & 82,4 & 16 & 47,1 & & \\
\multicolumn{2}{c}{$\geq 4,00$} & 6 & 17,6 & 18 & 52,9 & 12 & 52,2 \\
\multicolumn{2}{c}{ Total } & 34 & 100 & 34 & 100 & & \\
\hline
\end{tabular}

Keterangan:

M. Komp: Metode Komprehensif

M. Kon : Metode Konvensional

Selanjutnya perbandingan peningkatan rerata dari indikator pemahaman nilai nasionalisme, dapat dilihat pada grafik berikut.

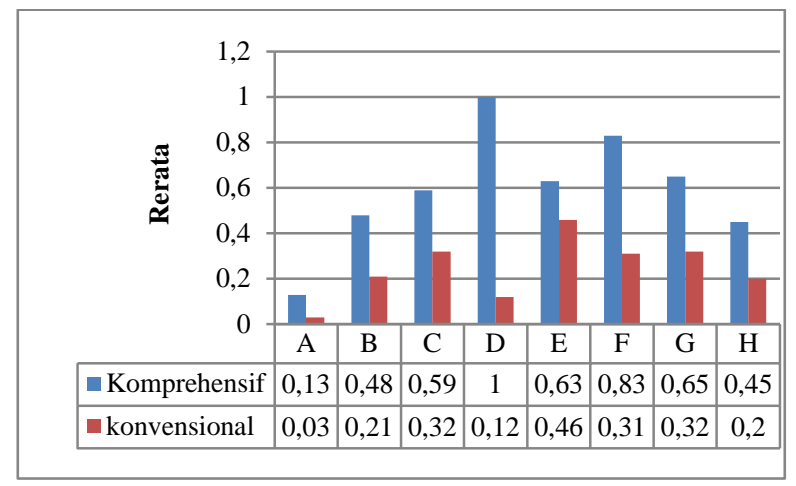

Gambar 10. Grafik Perbandingan Peningkatan

Rerata Indikator Sikap terhadap

Nilai Nasionalisme

Analisis Data

\section{Uji Prasyarat Analisis}

Uji Normalitas. Berdasarkan hasil pengujian normalitas pada penelitian ini, diperoleh nilai signifikansi pada data pemahaman nilai nasionalisme sebesar $0,087>0,05$ dan sikap terhadap nilai nasionalisme sebesar $0,200>0,05$, dapat disimpulkan bahwa sebaran penelitian ini berdistribusi normal.

Uji Homogenitas. Berdasarkan hasil uji homogenitas variansi dengan Lavene Test dan kovariansi dengan uji Box's M, diperoleh pemahaman nilai nasionalisme memiliki nilai sig $0,149>0,05$ dan sikap terhadap nilai nasionalisme memiliki nilai sig. 0,141>0,05, serta pada pengujian kovariansi dengan uji Box's M menunjukkan nilai sig 0,182>0,05 yang berarti bahwa asumsi homogenitas matrik kovariansi terpenuhi.

\section{Uji Hipotesis}

Berdasarkan hasil pengujian terhadap hipotesis pertema yaitu $\mathrm{H}_{\mathrm{a}}$ : terdapat perbedaan pada pemahaman nilai nasionalisme antara siswa yang menggunakan metode komprehensif (kelas eksperimen) dibandingkan dengan siswa yang tidak menggunakan metode komprehensif (kelas kontrol), diperoleh $F_{\text {hitung }}=12,070$ dengan $\rho=0,001<0,05$, dengan demikian hipotesis alternatif $\left(\mathrm{H}_{\mathrm{a}}\right)$ diterima.

Hasil pengujian terhadap hipotesis kedua yaitu $\mathrm{H}_{\mathrm{a}}$ : terdapat perbedaan pada sikap terhadap nilai nasionalisme antara siswa yang menggunakan metode komprehensif (kelas eksperimen) dibandingkan dengan siswa yang tidak menggunakan metode komprehensif (kelas kontrol), diperoleh $\quad F_{\text {hitung }}=13,436$ dengan $\rho=0,001>0,05, H_{a}$ diterima.

Pada hasil pengujian terhadap hipotesis ketiga yaitu $\mathrm{H}_{\mathrm{a}}$ : metode komprehensif efektif untuk mengembangkan nilai nasionalisme siswa (pemahaman nilai nasionalisme dan sikap terhadap nilai nasionalisme), diperoleh nilai sig <0,05 pada uji statistik Pillai's Trace, Wilks' Lambda, Hotelling's Trace, dan Roy's Largest Root, dengan demikian $\mathrm{H}_{\mathrm{a}}$ diterima.

Berdasarkan hasil temuan dan pengujian hipotesis pada penelitian ini, semua hipotesis diterima. Pembelajaran PPKn dengan menggunakan metode komprehensif lebih efektif untuk mengembangkan/meningkatkan nilai nasionalisme siswa dibandingkan dengan metode yang konvensional.Hal ini sesuai dengan pengujian hipotesis yang mengungkapkan bahwa: (1) terdapat perbedaan pada pemahaman nilai nasionalisme antara siswa yang mengikuti pembelajaran PPKn dengan menggunakan metode komprehensif dan siswa yang menggunakan metode konvensional, hal ini dapat dibuktikan dengan memperhatikan dan membandingkan peningkatan pada pemahaman nilai nasionalisme pada kelas eksperimen lebih besar jika dibandingkan dengan kelas kontrol yaitu sebesar 73,9\% dengan frekuensi 17 (kelas eksperimen) dan 69,6\% dengan frekuensi 16 (kelas kontrol), sedangkan pada pengujian hipotesis diperoleh 
$\mathrm{F}=12,070$ dengan $\rho=0,001<0,05$. Metode komprehensif efektif dalam mengembangkan nilai nasionalisme, karena adanya komunikasi antara guru dan peserta didik, siswa diajak untuk terlibat langsung dalam proses pendidikan nilai yang terintegrasi pada pembelajaran PPKn melalui cara-cara dalam metode komprehensif seperti yang diutarakan oleh Kirschenbaum (1995, p. 238) bahwa pentingnya pendidikan moral dan nilai-nilai komprehensif yang didalamnya termasuk keterampilan sosial dan dalam pengajarannya tidak cukup hanya dengan cara berbuat dan bertingkah laku, tetapi perlu adanya hubungan (interaksi) satu sama lain. Dalam berinteraksi, terdapat komponen yang vital dalam berkomunikasi yaitu keterampilan mengemukakan pendapat secara terbuka, dengan cara yang tidak melukai perasaan orang lain (keterampilan asertif) dan keterampilan mendengarkan dengan penuh pemahaman dan secara kritis (keterampilan menyimak). Sedangkan pada hipotesis 2) terdapat perbedaan pada sikap terhadap nilai nasionalisme pada pemahaman nilai nasionalisme antara siswa yang mengikuti pembelajaran PPKn dengan menggunakan metode komprehensif dan siswa yang menggunakan metode konvensional, hal ini dapat dibuktikan dengan memperhatikan dan membandingkan peningkatan pada peningkatan sikap terhadap nilai nasionalisme kelas eksperimen yaitu sebesar 73,95\% dengan frekuensi 17 dan pada kelas kontrol 52,2\% dengan frekuensi 12 , sedangkan pada hasil pengujian hipotesis diperoleh $F=13,436$ dengan $\rho=0,001<0,05$. Hal ini sesuai dengan apa yang menjadi tergat pembelajaran PPKn yang mengintegrasikan tiga ranah perkembangan jiwa yaitu pemahaman (kognitif), sikap (afektif) dan perilaku (praktik). Hal ini senanda dengan yang diutarakan Zuchdi (2008, pp.41-42):

Untuk menjadi warga negara yang efektif diperlukan keterampilan berkomunikasi yang baik. Dengan mengekspresikan sikap, kepercayaan, dan nilai-nilai yang efektif, kita akan lebih mungkin untuk memengaruhi orang lain sehingga nilai-nilai yang kita anut menjadi bagian dari nilai-nilai yang dianut oleh masyarakat secara luas.

Berdasarkan pendapat tersebut, diharapkan bahwa pemahaman yang benar pada suatu materi pembelajaran akan nilai-nilai dapat diwujudkan dalam sikap dan perilaku warga Negara. Pada hipotesis 3) metode komprehensif efektif untuk mengembangkan nilai nasionalisme (pemahaman nilai nasionalisme dan sikap terhadap nilai nasionalisme) dalam pembelajaran PPKn dibandingkan dengan metode konvensional. Hal ini dapat dibuktikan dari hasil uji multivariat menunjukkan bahwa keempat uji statistik (Pillai's Trace, Wilks' Lambda, Hotelling's Trace, dan Roy's Largest Root) memiliki sig $<0,05$, artinya pada taraf kepercayaan $95 \%$, penggunaan metode pembelajaran komprehensif memberikan efek yang cukup besar terhadap pemahaman nilai nasionalisme dan sikap nasionalisme secara keseluruhan. Pengintegrasian nilai-nilai nasionalisme ke dalam materi dan proses pembelajaran PPKn dapat membuat pembelajaran lebih bermakna, tidak hanya sekedar pencapaian kognitif saja tetapi juga afektif.

\section{Simpulan dan Saran}

Simpulan

Terdapat perbedaan pada pemahaman nilai nasionalisme dan sikap terhadap nilai nasionalisme antara siswa yang mengikuti pembelajaran PPKn dengan metode komprehensif dan siswa yang mengikuti pembelajaran dengan metode konvensional. Pembelajaran PPKn dengan menggunakan metode komprehensif lebih efektif dalam mengembangkan nilai nasionalisme (pemahaman nilai nasionalisme dan sikap terhadap nilai nasionalisme siswa) dibandingkan dengan metode konvensional. Saran

Kepala Sekolah sebagai pengambil kebijakan hendaknya menyarankan kepada para guru PPkn khususnya kelas VIII untuk melaksanakan pembelajaran dengan pengintegrasian pendidikan nilai dalam proses pembelajaran dengan menggunakan metode komprehensif agar proses pembelajaran lebih bermakna bagi siswa, karena hubungan antara guru dan siswa terbangun, potensi siswa juga lebih mungkin untuk berkembang secara menyeluruh dari aspek kognitif, afektif, dan perilaku. Siswa hendaknya lebih memaknai suatu nilai yang diberikan melalui materi yang disampaikan oleh guru, sehingga siswa tidak hanya sekedar paham akan tetapi mampu mewujudkannya melalui sikap yang diaplikasikan dalam kehidupan sehari-hari baik di lingkungan sekolah maupun masyarakat. 


\section{Daftar Pustaka}

Aman. (2014). Aktualisasi nilai-nilai kesadaran sejarah dan nasionalisme dalam pembelajaran sejarah di SMA. Jurnal Pendidikan Karakter, 1(2), 23-24. Dari http://journal.uny.ac.id/index.php/jpka /article/view/2174/1810.

Kirschenbaum, H. (1995). 100 ways to enhance value and morality in school youth settings. Boston: Allyn and Bacon.

Mardapi, D. (2008). Teknik penyusunan tes dan nontes. Yogyakarta: Mitra Cendekia Offset.

Muthoharoh, A.I. (2012). Pendidikan nasionalisme melalui pembiasaan di SD Negeri Kuningan 02 Semarang Utara. Unnes Civic Education Journal, 1(2).1-12. Dari http://journal.unnes.ac.id/sju/index.ph p/ucej/article/view/1010/1034

Puspita, L., Hasyim, A., \& Yanzi, H. (2013). Hubungan pemahaman materi tentang Pancasila dengan perubahan sikap nasionalisme siswa SMP. Jurnal Kultur
Demokrasi, 1(3), 1-15. Dari http://jurnal.fkip.unila.ac.id/index.php /JKD/article/view/2359/0

Sadono, M., Masruri, M. (2014). Keefektifan VCT dalam pembelajaran sejarah untuk meningkatkan nilai nasionalisme, demokrasi, dan multikultural. Harmoni Sosial: Jurnal Pendidikan IPS. Diakses pada tanggal 10 Juli 2015 dari

http://journal.uny.ac.id/index.php/hsjp i/article/view/2429>.

Winataputra, U.S. (2014). Diskursus aktual tentang paradigma Pendidikan Kewarganegaraan (PKn) dalam konteks Kurikulum 2013. Makalah disajikan dalam Seminar Nasional PKnAP3KNI, di Universitas Pendidikan Indonesia. Diakses pada tanggal 7 Juli 2015 dari http://ppkn.org/wpcontent/uploads/2014/02/MakalahProf-Udin_revisi-abstract.pdf

Zuchdi, D. (2008). Humanisasi pendidikan: menemukan kembali pendidikan yang manusiawi. Jakarta: PT. Bumi Aksara. 